\title{
Effect of Dried Moringa oleifera Leaves on the Nutritional and Organoleptic Characteristics of Cookies
}

\author{
Haneen Hamed Saleh Mouminah ${ }^{1}$
}

\begin{abstract}
In the present study, dried Moringa oleifera leaves powder (DMLP) were incorporated at different levels (5, 10 and $15 \%$ ) in cookies and their sensory and nutritional properties were evaluated. The results revealed that the contents of protein, dietary fiber, minerals in cookies increased with incorporation of increasing levels of DMLP. Sensory evaluation showed that cookies with acceptable quality and typical Moring $a$ leaf flavor could be obtained by incorporating DMLP up to $10 \%$. Thus, the nutritional quality of cookies could be enhanced by incorporating DMLP in a dose dependent manner.
\end{abstract}

Keywords: Moringa- Organoleptic- Cookies

\section{INTRODUCTION}

Moringa oleifera is one of the vegetables of the Brassica order and belongs to the family Moringaceae. The Moringaceae is a single genus family with 13 known species (Khawaja, et al., 2010).

Moringa oleifera is a small native tree of the subHimalayan regions of North West India, which is now indigenous to many regions in Africa, Arabia, South East Asia, the pacific and Caribbean Islands, and South America. Traditionally, besides being a daily used vegetable among people of these regions, the Moringa is also widely known and used for its health benefits. Among commoners, it has earned its name as 'the miracle tree' due to its amazing healing abilities for various ailments and even some chronic diseases. Several investigations were carried out to isolate bioactive compounds from various parts of the plant due to its various applications (Guevara, et al., 1999).

Moringa oleifera is a tropical tree possessing numerous economic applications, plus growing in international interest. Moringa tree is cultivated and used as a vegetable (leaves, green pods, flowers, roasted seeds), for spice (mainly roots), cooking, and cosmetic oil (seeds) and as a medicinal plant (all plant organs), (Rebecca, et al., 2006).

Moringa oleifera is a highly valuable plant, distributed in many tropical and subtropical countries. It has an impressive range of medicinal uses with high nutritional value. Different parts of this plant contain a profile of important minerals, and are a good source for protein, vitamins, $\beta$ - carotene, amino acids and various phenolics as well as antioxidants, anti-inflammatory nutrients and omega 3 and 6 fatty acid (Kasolo, et al., 2010).

Moringa plant provides a rich and rare combination of zeatin, qurcetin, kaempferol and many other phytochemicals. It is also a very important plant for its medicinal value. Various parts of the plant such as leaves, roots, seeds, bark, fruit, flowers and immature pods etc. as cardiac and circulatory stimulants, possess antitumour, antipyretic, antitiepileptic, antiinflammatory, antiulcer, antispasmodic, antihypertensive, cholesterol lowering, antioxidant, antidiabetic, antibacterial and antifungal (Bukar, et al., 2010).

Nutrition content of a plant plays an essential function in medicinal, nutritional, and therapeutic properties (AlKharusi, et al., 2009). It is believed that Moringa leave contains high source of vitamin $\mathrm{C}$, calcium, $\beta$ - carotene, potassium as well as protein. It works as an effective source of natural antioxidants. Due to the presence of several sorts of antioxidants such as flavonoids, ascorbic acid, carotenoids, and phenolics, Moringa is able to extend the period of safety in the food containing fats (Dillard and German, 2000; Siddhuraju and Becker, 2003).

The leaves can be eaten fresh, cooked, or stored as dried powder for many months without refrigeration, and reportedly promising as a food sources in the tropics because the tree is in full leaf at the end of the dry season when other foods are typically scarce 'ounce-forounce, Moringa leaves contain more vitamin A than carrots, more calcium than milk, more iron than spinach, more vitamin $\mathrm{C}$ than oranges, and more potassium than bananas, as well as the protein quality of moringa leaves rivals that of milk and eggs (Fahey, 2005).

Tumer, et al. (2015) suggested that Moringa leaves contain a potent mixture of direct and indirect antioxidants that can explain its various healthpromoting effects.

Nandave, et al.(2009) concluded that Moringa oleifera extract possesses significant cardioprotective effect, which may be attributed to its antioxidant, antiperoxidative, and myocardial preservative properties.

\footnotetext{
${ }^{1}$ Faculty of Home Economics, food and Nutrition department King Abdul Aziz University - Jeddah

Received October 8, 2015, Accepted November18, 2015
} 
Cookies are widely accepted and consumed in many countries and therefore offer a valuable supplementation vehicle for nutritional improvement. Cookies have been suggested as a good way to use composite flours as they are ready-to-eat, provide a good source of energy, and are consumed widely throughout the world (Arshad, et al., 2007). The term cookies, or biscuits as they are called in many parts of the world, refers to a baked product generally containing the three major ingredients flour, sugar, and fat. These are mixed together with other minor ingredients to form the dough (Mamat, et al., 2010). In the USA, the cookie and cracker manufacturing industry includes about 300 companies with combined annual revenue of about $\$ 11$ billion (Hodgen, 2004).

Several studies have been reported on utilization of green leafy vegetables in bakery products, such as dried Moringa oleifera and Tinospora cordifolia leaves in cookies (Dachana et al. 2010, Sharma et al. 2013), combination of normal / dehydrated M. koenigii and Coriandrum sativum in buns (Sudha, et al. 2013); M. koenigii to extend the shelf life of biscuits produced from blends of sorghum flour and wheat flour (Emmanuel, et al. 2012), curry leaf powder in chapatti, seasoned potatoes and cooked rice as a part of spice mixture (Shanthala and Prakash 2005), mint leaves in biscuits as a source of natural antioxidant (Shivani et al.2006), dried Amaranthus leaves in biscuit, cake, pakora, vada, namkpara and kurmura (Singh and Kawatra 2006) and cauliflower leaves in biscuits and shakarpara (Jood et al. 2001). All these studies were aimed to improve the nutritional qualities of the products. The aim of this study was to partially replace wheat flour with 5, 10 and $15 \%$ dried curry leaf powder and to measure organoleptic and nutritional characteristics resulting in cookies.

\section{MATERIALS AND METHODS}

Moringa leaves were washed with water to remove extraneous material. The leaves were dried at $50^{\circ} \mathrm{C}$ overnight. The dried leaves were coarsely powdered in a blender, sieved through $250 \mu \mathrm{m}$ sieve and stored in polythene bag.

\section{Preparation of blends}

Blends were prepared using mixture of wheat flour and Moringa oleifera leaves in the ratios of 100/0, 95/5, $95 / 10$ and $85 / 15 \mathrm{w} / \mathrm{w}$. The choice of these levels was made on the initial acceptability trials of the baked product.

\section{Cookie preparation}

The weight of flour used was adjusted to $14 \mathrm{~g} / 100 \mathrm{~g}$ moisture content. The amount of added water was calculated based on the moisture content in the blend.
All ingredients used in the cookies' formulation were commercially available(Table1). Cookies were prepared by using the AACC method (AACC, 2000) with slight modifications.

\begin{tabular}{ll} 
Table 1. Cookie baking formulation \\
\hline Ingredient & Quantity \\
\hline All-purpose Flour, sifted & 3 cups \\
Butter & 1 cup \\
Baking soda & 2 teaspoon \\
Eggs & 3 \\
Salt & $1 / 2$ teaspoon \\
Cinnamon & 1 and $1 / 2$ tablespoon \\
Sugar & 1 and $1 / 2$ cup \\
Chopped walnuts & 1 cup \\
Chopped raisins & 1 cup \\
\hline
\end{tabular}

Chemical Composition: Moringa oleifera leaves and prepared cookies were chemically analyzed for moisture, crude protein, fat, crude fiber and ash according to methods described in (AOAC, 2006). Total carbohydrates were calculated by difference. The energy value was calculated using the Atwater factors of 4, 9, and 4 for protein, fat and carbohydrate, respectively (Chaney, 2006). Total soluble fiber was determined by following the enzymatic method (Furda, 1981).

Total Minerals: Samples were wet acid-digested, using a nitric acid and perchloric acid mixture ( $\mathrm{HNO}: \mathrm{HClO}$, $5: 1 \mathrm{w} / \mathrm{v})$. The total amounts of $\mathrm{Ca}, \mathrm{Mg}, \mathrm{Fe}, \mathrm{Cu}, \mathrm{Mn}, \mathrm{Zn}$ and $\mathrm{Cr}$ in the digested samples were determined by atomic absorption spectrophotometry (ThermoElmental, Model 300VA, UK, 1969).

Sensory characteristics: The organoleptic characteristics of cookies were determined, using a taste panel, consisting of 10 judges. The panelists were asked to evaluate the products for appearance, color, texture, flavor and overall acceptability. The ratings were on a 9point hedonic scale, ranging from 9 (like extremely) to 1 (dislike extremely), for each organoleptic characteristic (Austin and Ram, 1971). Results were subjected to analysis of variance.

Statistical Analysis: Data were presented as means \pm standard deviation (SD). Values were statistically analyzed by one-way analysis of variance (ANOVA test) according to Sendecor and Cochran (1967) using SPSS 22 software package. Differences were considered significant at $\mathrm{P}$ values 0.05 using Duncan Multiple Range test.

\section{RESULTS}

Data presented in Table (2) showed the chemical composition of Moringa. Leaves. From the obtained data, it could be noticed that Moringa Leaves contained (on dry weight basis) $25.8 \%$ crude protein, $5.46 \%$ fat, $18.42 \%$ ash, $11.24 \%$ crude fiber, 39.10 carbohydrate and $308.64 \mathrm{Kcal}$ energy. 
Table 2. Chemical composition of Moringa Leaves (on dry weight basis)

\begin{tabular}{|c|c|}
\hline Components & $\%$ \\
\hline Organic mater & $81.57 \pm 0.38$ \\
\hline Ash & $18.42 \pm 0.38$ \\
\hline Crude Fiber & $11.24 \pm 0.68$ \\
\hline Fat & $5.46 \pm 0.19$ \\
\hline Crude Protein & $25.80 \pm 0.29$ \\
\hline Carbohydrate & $39.10 \pm 0.19$ \\
\hline Total metabolizable energy (Kcal/100gm) & $308.64 \pm 0.23$ \\
\hline \multicolumn{2}{|l|}{ Minerals (mg/100gm) } \\
\hline $\mathrm{Ca}$ & $1100.42 \pm 0.29$ \\
\hline $\mathrm{Mg}$ & $220.97 \pm 5.18$ \\
\hline $\mathrm{Fe}$ & $89.52 \pm 0.69$ \\
\hline $\mathrm{Cu}$ & $7.02 \pm 0.15$ \\
\hline $\mathrm{Mn}$ & $9.62 \pm 0.19$ \\
\hline $\mathrm{Zn}$ & $7.46 \pm 0.06$ \\
\hline $\mathrm{Cr}$ & $1.45 \pm 0.02$ \\
\hline
\end{tabular}

Data presented in Table(2) illustrate the minerals content of Moringa. Leaves It is obvious that Moringa Leaves contained 1100.42, 220.97, 89.52, 7.02, 9.62, 7.46 and $1.45 \mathrm{mg} / 100 \mathrm{gm} \mathrm{Ca}, \mathrm{Mg}, \mathrm{Fe}, \mathrm{Cu}, \mathrm{Mn}, \mathrm{Zn}$ and $\mathrm{Cr}$ respectively.

These results are in agreement with these reported by Busani et al., (2011) who found that the dried leaves of Moringa had crude protein levels of $30.0 \%$ and 19 amino acids. The dried leaves had the following mineral contents: calcium(3.65\%), phosphorus (0.3\%), magnesium $(0.5 \%)$, potassium $(1.5 \%)$, sodium $(0.164 \%)$, sulphur $(0.63 \%)$, zinc $(13.03 \mathrm{mg} / \mathrm{kg})$, copper $(8.25 \%)$, manganese $(86.8 \mathrm{mg} / \mathrm{kg})$, iron $(490 \mathrm{mg} / \mathrm{kg})$ and selenium $(363 \mathrm{mg} / \mathrm{kg})$. The values of amino acids, minerals and vitamins profiles reflect desirable nutritional balance.

Charles et al., (2011), stated that the percentages (\%) of proteins, moisture, fat, carbohydrates of fresh, and dried leaves were 11.9, 73.9, 1.1, and 10.6 and 27.2, $5.9,17.1$ and $38.6 \%$, respectively. Also, Charles et al., (2011) noticed that the minerals contents for the (Ca, $\mathrm{Mg}, \mathrm{K}, \mathrm{Fe}, \mathrm{Zn}$ and $\mathrm{P}$ ) were 847.1, 151.3, 549.6, 17.5, 1.3 and 111.5 and 2098.1, 406.0, 1922.0, 28.3, 5.4 and $351.1 \mathrm{mg} / 100 \mathrm{~g}$ (dry weight basis) in the fresh and dried Moringa oleifera leaves, respectively.

El- Massry, et al. (2013) demonstrated that dried leaves of Moringa contained high amounts of protein and crude fibers which were 26.79 and $18.67 \%$, respectively, the total carbohydrates contents were higher in fresh and dried leaves of Moringa oleifera, which were 37.85 and $35.90 \%$, respectively. In addition the ash content was 3.64 and $7.92 \%$, respectively. the analysis of minerals showed that the Moringa leaves were good sources for iron $(\mathrm{Fe})$ than that found in other parts of Moringa oleifera, which values were, 15.98 and
$27.76 \mathrm{mg} / 100 \mathrm{~g}$ (DWB) for fresh and dried leaves, respectively. Essential amino acids such as, methionine, valine, phenylalanine, leucine, lysine and tryptophan, which were $2.12,6.47,6.38,10.12,6.73$ and $2.17 \mathrm{~g} / 16$ $\mathrm{g} \mathrm{N}$, respectively, It could be also observed that the Moringa oleifera is reported to have high quality protein which could be easily digested and that is influenced by the quality of its amino acids.

Conclusively, it could be observed that the seeds and leaves of Moringa oleifera are good sources for ether extract, crude protein, ash, and crude fiber as other legumes.

The sensory characteristics of Dried Moringa Leaves Powder (DMLP) substituted cookies are summarized in Table (3). The sensory scores for color, taste, odor, texture

appearance and overall acceptability decreased with increasing levels of DMLP. The color of cookies changed from creamish white to greenish white. The taste was adversely affected at $15 \%$ level as the cookies had very big islands. The texture was very hard and the cookies showed gritty mouth feel and dominating DMLP taste. Replacement of flour with $10 \%$ and $15 \%$ dried Moringa leaves flour decreased the overall acceptability of cookies. The overall acceptability score for the control was 8.46 on a 9-point hedonic scale which decreased significantly from 7.98 to 7.00 respectively. Cookies made from blends containing 5\% level of dried Moringa flours did not differ significantly $(\mathrm{P}<0: 05)$ from the control.

Sensory evaluation showed that cookies with acceptable quality and typical curry leaf flavor could be obtained by incorporating Murraya koenigii leaves up to $10 \%$ (Drisya, et al., 2015). 
Table 3. The sensory characteristics of Dried Moringa Leaves Powder (DMLP) substituted cookies

\begin{tabular}{ccccccc}
\hline & \multicolumn{5}{c}{ Organoleptic properties } \\
\cline { 2 - 6 } & Color & Taste & Odor & Texture & Appearance & $\begin{array}{c}\text { Overall } \\
\text { acceptability }\end{array}$ \\
\hline Control & $8.50 \pm 1.22^{\mathrm{a}}$ & $8.15 \pm 1.54^{\mathrm{a}}$ & $8.73 \pm 1.24^{\mathrm{a}}$ & $8.35 \pm 1.16^{\mathrm{a}}$ & $8.55 \pm 1.38^{\mathrm{a}}$ & $8.46 \pm 1.06^{\mathrm{a}}$ \\
\hline Wheat: & \multicolumn{7}{c}{} & \\
DMLP \\
\hline $95: 5$ & $7.75 \pm 1.35^{\mathrm{b}}$ & $7.90 \pm 1.46^{\mathrm{a}}$ & $8.10 \pm 1.49^{\mathrm{b}}$ & $8.00 \pm 1.49^{\mathrm{ab}}$ & $8.13 \pm 1.42^{\mathrm{a}}$ & $7.98 \pm 1.24^{\mathrm{a}}$ \\
\hline $90: 10$ & $6.77 \pm 1.67^{\mathrm{c}}$ & $7.15 \pm 1.29^{\mathrm{b}}$ & $7.50 \pm 1.28^{\mathrm{c}}$ & $7.68 \pm 1.11^{\mathrm{b}}$ & $7.28 \pm 1.36^{\mathrm{b}}$ & $7.14 \pm 1.11^{\mathrm{b}}$ \\
\hline $85: 15$ & $6.73 \pm 1.54^{\mathrm{c}}$ & $6.82 \pm 1.52^{\mathrm{b}}$ & $7.42 \pm 1.37^{\mathrm{c}}$ & $7.50 \pm 1.22^{\mathrm{b}}$ & $7.23 \pm 1.41^{\mathrm{b}}$ & $7.00 \pm 0.98^{\mathrm{b}}$ \\
\hline
\end{tabular}

Scores were: 9 = like extremely to $1=$ dislike extremely

abc means in the same column with different superscripts are different significantly $(\mathrm{P}<0.05)$

Table 4. Chemical composition of Cookies supplemented with DMLP

\begin{tabular}{lccccccc}
\hline Content & $\begin{array}{c}\text { Organic } \\
\text { mater }\end{array}$ & Ash & Crude fiber & Fat & $\begin{array}{c}\text { Crude } \\
\text { Protein }\end{array}$ & Carbohydrate & $\begin{array}{c}\text { Total } \\
\text { metabolizable } \\
\text { energy } \\
\text { Wheat: }\end{array}$ \\
$\begin{array}{c}\text { (Kcal/100gm) } \\
\text { DMLP }\end{array}$ & & & & & & & \\
\hline $100: 0$ & $98.27 \pm 0.04^{\mathrm{a}}$ & $1.73 \pm 0.04^{\mathrm{b}}$ & $1.16 \pm 0.07^{\mathrm{b}}$ & $21.44 \pm 0.18^{\mathrm{c}}$ & $8.91 \pm 0.01^{\mathrm{b}}$ & $66.76 \pm 0.23^{\mathrm{a}}$ & $495.64 \pm 0.81$ \\
\hline $95: 5$ & $98.24 \pm 0.03^{\mathrm{a}}$ & $1.77 \pm 0.04^{\mathrm{b}}$ & $2.63 \pm 0.95^{\mathrm{ab}}$ & $22.69 \pm 0.04^{\mathrm{b}}$ & $9.73 \pm 0.33^{\mathrm{ab}}$ & $63.19 \pm 1.36^{\mathrm{b}}$ & $495.89 \pm 3.75$ \\
\hline $90: 10$ & $97.45 \pm 0.0^{\mathrm{b}}$ & $2.55 \pm 0.01^{\mathrm{a}}$ & $2.70 \pm 0.85^{\mathrm{ab}}$ & $24.12 \pm 0.83^{\mathrm{a}}$ & $10.38 \pm 0.17^{\mathrm{a}}$ & $60.26 \pm 0.84^{\mathrm{c}}$ & $499.62 \pm 7.54$ \\
\hline $85: 15$ & $97.73 \pm 0.04^{\mathrm{b}}$ & $2.32 \pm 0.04^{\mathrm{a}}$ & $3.11 \pm 0.57^{\mathrm{a}}$ & $23.63 \pm 0.36^{\mathrm{ab}}$ & $9.77 \pm 0.60^{\mathrm{ab}}$ & $61.21 \pm 0.84^{\mathrm{c}}$ & $496.23 \pm 3.63$ \\
\hline
\end{tabular}

${ }^{a b c}$ means in the same column with different superscripts are different significantly $(\mathrm{P}<0.05)$

Table 5. Minerals composition of Cookies supplemented with DMLP

\begin{tabular}{|c|c|c|c|c|c|c|c|}
\hline $\begin{array}{l}\text { Wheat: } \\
\text { DMLP }\end{array}$ & $\mathbf{C a}$ & Mg & $\mathbf{F e}$ & $\mathbf{C U}$ & Mn & Zn & $\mathrm{Cr}$ \\
\hline 100:0 & $67.58 \pm 2.55^{\mathrm{c}}$ & $89.95 \pm 0.60^{\mathrm{d}}$ & $4.06 \pm 0.09^{\mathrm{d}}$ & $6.17 \pm 0.23^{\mathrm{a}}$ & $1.29 \pm 0.02$ & $4.09 \pm 0.06^{\mathrm{a}}$ & $1.24 \pm 0.01^{\mathrm{c}}$ \\
\hline $95: 5$ & $56.35 \pm 0.15^{\mathrm{d}}$ & $98.87 \pm 0.35^{\mathrm{c}}$ & $18.77 \pm 0.02^{\mathrm{b}}$ & $5.59 \pm 0.06^{\mathrm{b}}$ & $1.37 \pm 0.04$ & $3.90 \pm 0.21^{\mathrm{ab}}$ & $2.89 \pm 0.06^{\mathrm{a}}$ \\
\hline 90:10 & $71.26 \pm 0.01^{\mathrm{b}}$ & $132.52 \pm 0.33^{\mathrm{b}}$ & $15.99 \pm 0.33^{\mathrm{c}}$ & $5.54 \pm 0.13^{b}$ & $1.17 \pm 0.04$ & $2.48 \pm 0.05^{\mathrm{c}}$ & $2.72 \pm 0.04^{\mathrm{b}}$ \\
\hline $85: 15$ & $103.08 \pm 0.06^{\mathrm{a}}$ & $138.61 \pm 0.21^{\mathrm{a}}$ & $31.88 \pm 0.53^{\mathrm{a}}$ & $4.66 \pm 0.02^{\mathrm{c}}$ & $1.26 \pm 0.03$ & $3.72 \pm 0.04^{\mathrm{b}}$ & $2.31 \pm 0.00^{\mathrm{c}}$ \\
\hline
\end{tabular}

abcd means in the same column with different superscripts are different significantly $(\mathrm{P}<0.05)$

\section{Nutritional characteristics of cookies}

The total ash content increased with increase in DMLP indicating increase in the mineral contents in the cookies. The fat content of control and cookies with different levels of DMLP ranged between 21.44 to $24.12 \%$. The protein content increased from 8.91 to $9.73,10.38$ and $9.77 \%$ with addition of 5,10 and $15 \%$ DMLP respectively (Table 4). Improvement in the nutritional characteristics, such as minerals, dietary fiber, protein, antioxidant activity and shelf life with the use of green leafy vegetables in buns, cookies, biscuits have also been reported (Dachana et al. 2010,Sudha et al. 2013; Sharma et al. 2013; Emmanuel et al. 2012; Shivani et al. 2006). The dietary fiber for control cookies was $1.16 \%, 5 \%$ DMLP cookies (2.63\%), 10 $\%$ DMLP cookies $(2.70 \%)$ and $15 \%$ DMLP cookies $(3.11 \%)$.

There was significant enhancement $(p<0.05)$ in iron content of cookies with incorporation of DMLP. The calcium content of control cookies was $67.58 \mathrm{mg} \%$ and showed significant increase $(\mathrm{p}<0.05)$ on blending with DMLP. This may be attributed to the higher calcium content of DMLP. Addition of DMLP with 5, 10 and $15 \%$ increased the $\mathrm{Mg}$ content in a dose dependent manner as a compared with control. Iron content increased significantly $(\mathrm{p}<0.05)$ from $4.06 \mathrm{mg} / 100 \mathrm{gm}$ for cookies in control group to $8.77,15.99$ and 31.88 $\mathrm{mg} / / 100 \mathrm{gm}$ for cookies supplemented with 5, 10, 15\% Dried Moringa Leaves Powder (DMLP). Hence, the cookies supplemented with DMLP were found to possess higher nutritive profile than the control with only slight increase in fat content but other nutrients and beneficial components (protein, calcium, iron and dietary fibers) increased significantly in the DMLP incorporated cookies in a dose dependent manner (Table 5).

Baked snack foods such as bread and cookies are widely consumed in every part of the world and have become an attractive target for feeding and nutrition 
improvement programs among low-income groups and disaster relief agencies (Claughton and Pearce 1989).

Ogunsina, et al. (2011) demonstrated that replacement of wheat flour with $10 \%, 20 \%$ and $30 \%$ debittered moringa seed (DBMS) grits was found to affect cookies quality. Cookies with 20\% DBMS grits had the nutty taste of moringa seeds and were acceptable. Cookies with 20\% DBMS grits had more protein, iron and calcium.

Through all data concerning different compounds existing in Moringa oleifera, it could be clearly concluded that Moringa is very rich in many important nutrients to human health such as proteins, fiber, calcium, iron and zinc. It has been proved that it could be practical to utilize different parts of Moringa in producing very important and palatable economic products such as moringa tea, moringa juice and cooked seeds. It is also recommended to expand the area cultivated with moringa in the future.

\section{REFERENCES}

AACC (2000): Approved methods of the American Association of Cereal Chemists, $10^{\text {th }}$ ed. Methods 44-15 A, 44-40. The Association, St. Paul, MN, US.

Al-Kharusi, L.; Elmardi, M. and Ali, A, (2009): Effect of mineral and organic fertilizers on the chemical characteristics and quality of date fruits. Int J Agri Biol, 11, 290-6.

American Association of Cereal Chemists (AACC). (2000): Approved methods of American association of cereal chemists, $\left(9^{\text {th }}\right.$ ed). St.Paul, Minnesota

AOAC (2006): Official Methods of Analysis of AOAC International (2000). 20th ed. AOAC International, Arlington, VA, USA.

Arshad, M. Anjum, F. and Zahoor, T. (2007). Nutritional assessment of cookies supplemented with defatted wheat germ. Food Chemistry, 102, 123e-128.

Austin, A., and Ram, A. (1971): Studies on chapati making quality of wheat, Indian Council of Agricultural Research, New Delhi. Technical Bulletin, 31, 96-101.

Bukar, A.; Uba, A. and Oyeyi, T. (2010): Antimicrobial profile of Moringa oleifera Lam. extract against some food - borne microorganisms. Bayero Journal of Pure and Applied Science, 3 (1) 43 - 48.

Busani, M.,; Patrick, J. ; Arnold, H and Voster, M. (2011): Nutritional characterization of Moringa (Moringa oleifera Lam.) leaves. African Journal of Biotechnology, 10 (60): 12925 - 12933.

Chaney, S. (2006): Principles of Nutrition I: Macronutrients. In: Devlin, T.M. (ed.), Textbook of Biochemistry, with Clinical Correlation, 6th ed. John Wiley and sons, New York, pp: 1071-1090.
Charles, W.; Marcel, D. Aly, S.; Phillippe, A. and Sabadenedyo, A. (2011): Determination of chemical composition and nutritional values of Moringa oleifera leaves. Pakistan Journal of Nutrition. 10(3):264 - 268.

Claughton, S. and Pearce, R. (1989): Protein enrichment of sugarsnap cookies with sunflower protein isolate. J Food Sci 54:354-356.

Dachana, K.; Jyotsna, R.; Indrani, D. and Prakash, J. (2010): Effect of dried Moringa (Moringa oleifera Lam.) leaves on rheological, microstructural, nutritional, textural and organoleptic characteristics of cookies. J Food Quality 33:60-67.

Dillard. C. and German, J. (2000): Review Phytochemicals: nutraceuticals and human health. J Sci Food Agric, 80, 1744-6.

Drisya, C.; Swetha, B.; Velu, V.; Indrani, D. and Singh, R. (2015): Effect of dried Murraya koenigii leaves on nutritional, textural and organoleptic characteristics of cookies. J Food Sci Technol. 52(1):500-506.

El - Massry, f.; Mossa, M. and Youssef, S. (2013): Moringa Oleifera Plant Value and Utilization in Food Processing. Egypt. J. Agric. Res., 91 (4).

Emmanuel, G.; Omolara, O. and Michael, O. (2012): Effect of curry spice (Murraya Koenigii) on the shelf life of cookies (biscuit) produce from sorghum flour blends with wheat flour. Glob J Sci Front Res Biol Sci 12: No 6-C Ver. 1.

Fahey, J. (2005): Moringa oleifera: A Review of the Medical Evidence for Its Nutritional, Therapeutic, and Prophylactic Properties. Part 1. Trees for Life Journal. 1:5

Furda, I. (1981): Simultaneous analysis of soluble and insoluble dietary fibre. In W. P. T. James \& O. Theander (Eds.), The analysis of dietary fibre in food (pp. 163172). New York: Marcel Dekker.

Guevara, A.; Vargas, C. and Sakurai, H. (1999): An antitumour promoter from Moringa oleifera Lam. Mutat Res, 440,181-188.

Hodgen, D. (2004). Cookie and cracker manufacturing. United States Department of Commerce/International Trade Administration.

Jood, S.; Yadav, S.; Gupta, M. and Khetarpaul, N. (2001): Effect of Storage on Organoleptic Characteristics and Nutritional Evaluation of $\beta$ Carotene and Iron-Rich Products. J Food Comp Anal 14:591-600.

Kasolo, J.; Bimenya, G. and Ojok, L. (2010): Phytochemicals and uses of Moringa oleifera leaves in Ugandan rural communities. J Med Plants Res, 4, 753-577.

Khawaja, T.; Tahira, M. and Ikram, U. (2010): Moringa oleifera: a natural gift - A review. J Pharm Sci Res, 2, 775-781.

Mamat, H., Abu-Hardan, M. and Hill, S. (2010). Physicochemical properties of commercial semi-sweet biscuit. Food Chemistry, 121(4), 1029e1038. 
Nandave, M.; Ojha, S.; Joshi, S.; Kumari, S. and Arya, D. (2009): Moringa oleifera leaf extract prevents isoproterenol-induced myocardial damage in rats: evidence for an antioxidant, antiperoxidative, and cardioprotective intervention. J. Med. Food. 12(1):47-55.

Ogunsina, B.; Radha, C. and Indrani, D. (2011): Quality characteristics of bread and cookies enriched with debittered Moringa oleifera seed flour. International Journal of Food Sciences and Nutrition. 62(2): 185-194.

Rebecca, H.S.U., M. Sharon, A. Arbaunsyah and D. Lucienne. 2006. Moringa oleifera: medicinal and socio economic uses: International Course on Economic Botany. National Herbarium Leiden, Netherlands S. PP. $2-6$.

Sendecor, G. and Cochran, W. (1967): Statistical Methods. The Iowa State Univ. Press, Ames, U.S.A. $6^{\text {th }}$ ed.

Shanthala, M. and Prakash, J. (2005): Acceptability of curry leaf (Murraya koenigii) incorporated products and attitude toward consumption. J Food Proc Pres 29:33-44.
Sharma, P.; Velu, V.; Indrani, D. and Singh, R. (2013): Effect of dried guduchi (Tinospora cordifolia) leaf powder on rheological, organoleptic and nutritional characteristics of cookies. Food Res Int 50:704-709.

Shivani, B.; Asna, U. and Prabhasankar, P. (2006): Effect of incorporation of mint on texture, color and sensory parameters of biscuits. Int J Food Prop 9(4):691-700.

Siddhuraju, P. and Becker, K. (2003):Antioxidant properties of various solvent extract of total phenolic constituent from three different agroclimatic origins of drumstick tree (Moringa oleifera Lam.) leaves. J Agri Food Chem, 51, 2144-5.

Singh, G. and Kawatra, A. (2006): Development and nutritional evaluation of recipes prepared using fresh and dried amaranthus leaves. J Food Sci. Tech. 43(5):509-51.

Sudha, M.; Rajeswari, G. and Venkateswara Rao, G. (2013): Chemical composition, rheological, quality characteristics and storage stability of buns enriched with coriander and curry leaves. J Food Sci. Technol. 51(12):3785-93.

Tumer, T.; Rojas - Sva, P.; Poulev, A. and Raskin, I. (2015): Direct and indirect antioxidant activity of polyphenol- and isothiocyanate-enriched fractions from Moringa oleifera. $\mathrm{J}$ Agric Food Chem. 63(5):1505-1513.

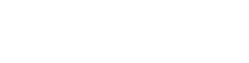 \\ تأثير أوراق الموربنجا المجفهة عل الخصائ التخوبة والهسية المضوبة للكوكيز \\ حنين حلمد صالح مؤمنة}

والمعان مل الكال عسيوم والحدي 2 والزن كـ ف في أوراق

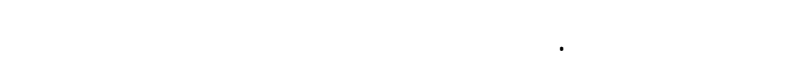

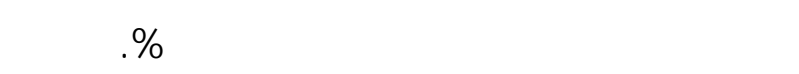

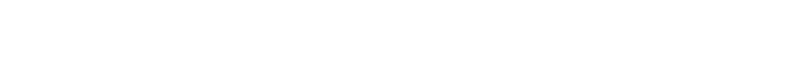

المورينجا المجففة المستخمة.
لمتهوفت هذه الدرلسة التعرف على تأثير لمتبدل دقيق

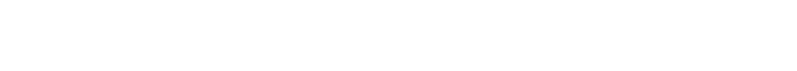

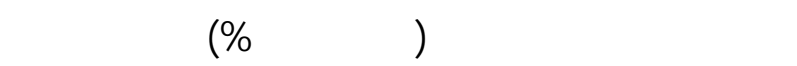

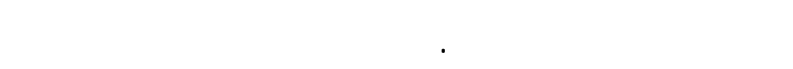

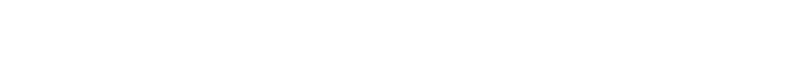

